\title{
Commodity frontiers and the transformation of the global countryside: a research agenda†
}

\author{
Sven Beckert ${ }^{1}$, Ulbe Bosma ${ }^{2 \star}$, Mindi Schneider ${ }^{3}$ and Eric Vanhaute ${ }^{4}$ \\ ${ }^{1}$ Department of History, Harvard University, ${ }^{2}$ International Institute of Social History, Cruquiusweg 31, 1019 AT Amsterdam. \\ VU University, De Boelelaan 1105, 1081 HV Amsterdam, ${ }^{3}$ Sociology of Development and Change, Wageningen University \\ and ${ }^{4}$ Department of History, Ghent University \\ *Corresponding author. E-mail: ubo@iisg.nl, u.t.bosma@vu.nl
}

\begin{abstract}
Over the past 600 years, commodity frontiers - processes and sites of the incorporation of resources into the expanding capitalist world economy - have absorbed ever more land, ever more labour and ever more natural assets. In this paper, we claim that studying the global history of capitalism through the lens of commodity frontiers and using commodity regimes as an analytical framework is crucial to understanding the origins and nature of capitalism, and thus the modern world. We argue that commodity frontiers identify capitalism as a process rooted in a profound restructuring of the countryside and nature. They connect processes of extraction and exchange with degradation, adaptation and resistance in rural peripheries. To account for the enormous variety of actors and places involved in this history is a critical challenge in the social sciences, and one to which global history can contribute crucial insights.
\end{abstract}

Key words: Commodity frontiers; commodity regimes; capitalism; global countryside; resource extraction; global history

The history of the making of the modern world is a history of the expansion of commodity frontiers, a historical process so spatially, socially and structurally all-encompassing that it still awaits its persuasive analysis. Over the past 600 years, since the inception of the capitalist revolution, these commodity frontiers - processes and sites of the incorporation of resources (land, energy, raw materials, knowledge and labour) - have moved at ever-accelerating speed across vast areas of the globe, incorporating ever more land, labour and natural resources. Flatlands, valleys, forests, marine spaces and mountains have been farmed, logged, fished and quarried to provide raw materials and food for a rapidly urbanizing and industrializing global economy, extractive processes that have been crucial drivers of capitalism's expansion.

Consider a product as common and banal as sugar. In Europe, it began its commodity life as a luxury product available in small quantities to the very richest - the Parisian aristocracy or Venetian merchants. By the fifteenth century, sugar production grew. As European power expanded into the Atlantic, Italian and Iberian capitalists turned the Canary Islands, Madeira and São Tomé into vast sugar estates, drawing on dispossessed land and enslaved labour to set in motion a machinery of accumulation. A century later, Flemish and Dutch capitalists moved this slavery-sugar complex to Brazil and then the Caribbean, turning one island after another into

\footnotetext{
${ }^{\dagger}$ The authors would like to thank Pepijn Brandon, Philip McMichael and Marcel van der Linden for their valuable comments.

(C) The Author(s), 2021. Published by Cambridge University Press. This is an Open Access article, distributed under the terms of the Creative Commons Attribution-NonCommercial-ShareAlike licence (http://creativecommons.org/licenses/by-nc-sa/4.0), which permits non-commercial re-use, distribution, and reproduction in any medium, provided the same Creative Commons licence is used to distribute the re-used or adapted article and the original article is properly cited. The written permission of Cambridge University Press must be obtained prior to any commercial use.
} 
sugar-producing slave-labour camps. When mid-seventeenth-century British traveller Richard Ligon looked at one such island, Barbados, he was awed by the 'vast Revenue this little spot of ground can produce.' ${ }^{1}$ So much wealth had been accumulated, yet, as he noted, it had been accumulated 'without the help of Magic or Enchantment.'

It was not magic that turned dense forests into cane producing plantations at awe-inspiring speed, but enslaved workers and capital-rich merchants and planters. After Barbados, the sugar frontier moved to Jamaica, Saint-Domingue and Louisiana, with Cuba, by the nineteenth century, the most productive sugar island in the world, the one that married the most modern technologies, steam engines, to the most violent system of labour mobilization, slavery. At the same time, Dutch colonial administrators began turning Java into yet another major sugar producer, just after Chinese capitalists had transformed their newly acquired island of Taiwan into a significant source of sugar for its domestic markets. Then, in the nineteenth century, as the Caribbean sugar frontier faced the emancipation of its workers, new virgin sugar territories such as Mauritius, Guyana, Réunion and Fiji arose, worked by indentured Indian and Chinese labourers producing for global markets. Later that century, beet sugar began being produced on yet another commodity frontier in the temperate zones of Europe and North America, one that used new systems of peasant labour. And the movement continues: huge sugar frontiers are being created in western Brazil, powered by transnational corporations, including giant German and French beet sugar producers, marked by a high degree of vertical integration and deep entanglements with finance capital. More than just a source of calories, the vastly increased sugar supply is now being used to make ethanol, produced and sold as 'green' or 'sustainable' bio fuel.

Soy, another important contemporary commodity frontier and source of plant-based fuels, has a shorter but no less volatile history. In the past 60 years, global soy production has increased by a stunning $1000 \%$. By $2018 / 19$, the world produced 360 million tons of soy on more than 125 million hectares of land, or more than three times the surface area of the Netherlands. ${ }^{3}$ Of ancient Chinese origins, soy exploded across the globe in the twentieth century, led by state-sponsored agricultural policies and North Atlantic-based transnational agribusiness firms, mainly in the USA, which produced the majority of the world's soy into the 1990s. Since then, businesses have pushed new soy frontiers into the southern cone of Latin America - Argentina, Paraguay and Brazil - where today collectively more than half of all soybeans are grown. Vast areas of forest and cerrado (savannah) have been ploughed under, and helped by chemistry, genetics and agricultural machinery, turned into exceedingly productive fields. In the meantime, soy consumption has pivoted to China, which now accounts for almost two-thirds of the global soy trade. As elsewhere, soy in China is used principally as livestock feed, powering an expansion in Chinese pork production and underwriting a massive global increase in meat consumption.

Soy and sugar are just two examples of the many commodity frontiers that have moved across the globe in the past six centuries. There are many more: coffee relocated from its ancient home on the Arabian Peninsula to Java; from there to the Caribbean, then, in the nineteenth century, to Brazil and Central and East Africa, where it is now considered a 'traditional' crop. Cotton, the fuel of the Industrial Revolution, migrated from its ancient homes in South Asia, Africa and Central America first into the Caribbean and Brazil, through a period of wild expansion in the USA, and then, coming full circle, back to Egypt, western India, West Africa and Central Asia. When copper started to feed the Second Industrial Revolution, its mining frontier travelled from Europe to Chile, the Congo and Michigan. Palm oil moved from West Africa to Southeast Asia, tea from China to India, wheat from its ancient homes in the Fertile Crescent into the vast steppes of

\footnotetext{
${ }^{1}$ Richard Ligon, A True and Exact History of the Island of Barbados (London: Peter Parker, 1673), 96.

${ }^{2}$ Ligon, A True and Exact History, 109.

${ }^{3}$ See United States Department of Agriculture, Foreign Agricultural Service, Circular Series, June 2020, World Agricultural Production.
} 
eastern Europe to Argentina and the American Midwest and coal from Europe to North America, Russia, China, India and Australia. Huge territories on all continents have seen their ecologies and societies radically reconfigured by the incursion of new commodity frontiers, outside capital, migrant workers and innovative technologies. Millions of people have laboured on these commodity frontiers, often under coercion, and huge wealth has streamed from fields and mines into the coffers of capital-rich urbanites, while provisioning industrial workers with food, and machines with supplies. In the process, native peoples have been dispossessed of land and rights, and the countryside has been endlessly reconfigured into a source for global capitalist growth.

Crucially, commodity frontiers are variable in terms of place and commodity, and they change over time. In 1700, for example, most cotton was grown by peasant producers on land they owned or rented, then sold to merchant middlemen. In 1800, most cotton traded on global markets was grown by enslaved cultivators on land taken from indigenous inhabitants; enslavement and possession both funded by European metropolitan capital. Another 100 years later, in 1900, sharecroppers and tenant farmers drawing on European capital and enabled by massive state-directed infrastructure projects and legal interventions produced cotton for global markets. There was also significant diversity within given moments in time. In 1800, for instance, sugar was produced in some regions of the world by enslaved workers, in others by peasant cultivators and elsewhere by wage workers.

The concept of commodity frontiers is a powerful lens through which to analyse capitalism's history. It helps us understand on an empirical and conceptual level how ongoing incorporations of new reservoirs of labour, land and nature have constituted capitalism's extraordinary dynamics - especially its ability to produce ever more goods. Focusing on the long history of these commodity frontiers allows us to analyse how frontier expansion has generated shifting sets of seemingly localized activities to secure access to labour, land and nature for globalized commodity production, helping us come to terms with the diversity of outcomes at any given moment and their shift over time. Seeing how commodity frontiers have moved for centuries, taking on very different characteristics - transitions marked by booms and busts, inherent ecological and social limits including resistance, and altered by the very contradictions they produced let us better understand some of the fundamental dynamics of capitalism and its connection to and subsumption of new spaces, new countrysides and new forms of nature. And, crucially, looking at commodity frontiers makes it strikingly clear that it is impossible to fully understand capitalism without thinking just as much about the countryside as about cities, about agriculture as about industry.

Commodity frontiers are core constituents of the modern world. Understanding how and why they have expanded, moved and adapted over time is thus a key step in a better understanding and analysis of the global history of capitalism. But it includes great challenges: how to account for the enormous variety and specificity of actors and places involved in this history, the dizzying number of changes that have taken place as well as their almost unfathomable scale, without losing sight of the broad movements of global capitalism and its systemic transformations? It is to this fundamental social sciences challenge that global history can contribute crucial insights.

\section{Capitalism and commodity frontiers}

Considering the spectacular rise in the growing of agricultural commodities and the mining of minerals in the past centuries, and the stunning and ongoing social and environmental effects of their production and circulation, it is not surprising that many scholars from a variety of disciplines have tried to grasp the underlying mechanisms of commodity frontier expansion.

Economists have contributed much to our understanding of these issues, especially their discussion of whether and to what extent capitalism can resolve the social and ecological crises it has 
created. We learn from Edward Barbier's monumental Scarcity and Frontiers that over the past centuries, some commodity frontiers sustained successful resource-based development, while many more collapsed under social and ecological pressures. ${ }^{4} \mathrm{We}$ also discover that capitalist production has created and extracted a wealth of new agricultural commodities and minerals across the world, while polluting bodies of water, land and people, depleting and salinizing soils and degrading the very conditions of its own reproduction. Many economists conceptualize these processes by emphasizing that capitalism tends to externalize social and ecological costs, and that the best way to correct such imbalance is to internalize them. In both economic research and policymaking, internalizing externalities has become a widely accepted approach to furthering global sustainability. Neoclassical economists are especially optimistic about such ecological accounting. Paul Collier, one of this field's most prominent voices, promotes an analytical tool he calls 'right prices' and highlights the role of 'inclusive and transparent institutions' in defining and regulating such prices. ${ }^{5}$

Ecological economists, on the other hand, have looked at the same set of facts and come to very different understandings. Economist Joan Martinez-Alier, along with human ecologists working on distributional conflicts such as Alf Hornborg, for example, are sceptical that capitalist externalities can be priced into submission. They offer alternative conceptions of how to define capitalism's ecological problems, seeing them as the political results of uneven distribution. ${ }^{6}$ They deploy concepts such as social metabolism and unequal ecological exchange to analyse how the flows of energy and materials between places and peoples generate and maintain inequalities. These scholars contend that the capitalist system, rather than being able to self-correct by pricing externalities, is based on crushing forms of ecological debt created by rich nations underwriting their growth with the resources of poor nations. For these scholars, past centuries have been marked by industrializing societies - almost always colonial powers - compensating for their ecological deficits by imperialist exploitation. ${ }^{7}$ By opening new frontiers of commodity cultivation, production, extraction and waste disposal, these countries have exported problems of pollution, soil degradation, poor labour conditions and social upheaval to poorer countries. Geographer David Harvey one of the most prominent voices in this debate - refers to this process as capital's 'spatial fix' - the extraction of resources by dispossession and labour from local communities, resulting in highly uneven development. ${ }^{8}$

Development studies scholars provide yet another set of approaches to understanding commodity frontiers by asking why many resource-rich countries tend to be characterized by low levels of economic growth, massive economic inequality and high rates of poverty. Neoclassical economic explanations for this 'paradox of plenty' or 'resource curse' tend to centre on issues of incorrect pricing, misallocation of development revenues and inadequate institutional

\footnotetext{
${ }^{4}$ See United States Department of Agriculture, Foreign Agricultural Service, Circular Series, June 2020, World Agricultural Production.

${ }^{5}$ See Paul Collier, The Plundered Planet. Why We Must - and How We Can - Manage Nature for Global Prosperity (Oxford: Oxford University Press, 2010).

${ }^{6}$ Alf Hornborg, "Zero-Sum World. Challenges in Conceptualizing Environmental Load Displacement and Ecologically Unequal Change in the World-System," International Journal of Comparative Sociology 50, no. 3-4 (2009): 237-62.

${ }^{7}$ See Alf Hornborg, "Introduction: Environmental History as Political Ecology," in Rethinking Environmental History. World-System History and Global Environmental Change, ed. Alf Hornborg, J.R. McNeill, Joan Martinez-Alier (Lanham: Altamira Press, 2007), 1-26.

${ }^{8}$ David Harvey, The Limits to Capital (Oxford: Blackwell, 1982); David Harvey, “The Geopolitics of Capitalism," in Social Relations and Spatial Structure, ed. Derek Gregory, John Urry (Basingstoke, Hampshire: Macmillan, 1994), 128-63; David Harvey, Spaces of Capital: Towards a Critical Geography (Edinburgh: Edinburgh University Press, 2001); Stephen H. Bunker, "Natural Values and the Physical Inevitability of Uneven Development Under Capitalism," in Rethinking Environmental History. World-System History and Global Environmental Change, ed. Alf Hornborg, J.R. McNeill, Joan Martinez-Alier (Lanham: Altamira Press, 2007), 239-258; Alf Hornborg, "Zero-Sum World".
} 
quality and oversight. ${ }^{9}$ Critical economists and political ecologists, especially in Latin America, argue, in contrast, that this outcome is not a paradox, but rather the direct result of outside actors and institutions extracting minerals, raw materials and forest and agricultural resources and exporting them along with the water, energy, labour and knowledge that they embody. To conceptualize that impact of commodity frontier expansion, these thinkers use notions of extractivism, neo-extractivism and post-extractivism. ${ }^{10}$ Other scholars, including Mattias Borg Rasmussen, Christian Lund and Nancy Peluso, use the concept of territorialization to explain how patterns of resource exploration, extraction and commodification have dissolved existing social orders and reordered spaces. The reshaping of social and economic orders around new resource frontiers profoundly reworks patterns of authority and institutional architectures such as property systems, political jurisdictions, rights and social contracts. ${ }^{11}$

Insights from these debates are germane for studying the social and environmental foundations and the effects of capitalism's commodity frontiers in the global countryside. But even as various disciplines converge around studying the social and environmental foundations and effects of capitalism's commodity frontiers, their concepts remain siloed in discrete literatures. What is more, many (though not all of them) tend to focus on contemporary problems, their analysis limited by a failure to fully consider the many centuries of commodity frontier expansion.

\section{The importance of history}

Historical concepts are crucial, however, in situating present issues in longer trajectories to highlight the patterns that will ultimately help us find new analytical tools to grapple with our present. Of course, there is a long tradition of looking at capitalism historically, and indeed a distinguished group of social scientists - from Werner Sombart and Fernand Braudel to Immanuel Wallerstein and Alain Bihr - has argued that global capitalism emerged on the eve of the Columbian voyages across the Atlantic, that capitalism, in fact, was born global. ${ }^{12}$ For this group of scholars and others in that tradition, commodity frontier expansion was a key marker of capitalism from its very beginning.

No one has done more to understand capitalism as a system encompassing distant places and people than Terence Hopkins and Immanuel Wallerstein, the developers of the concept of the commodity chain. ${ }^{13}$ Their aim was to show the emergence of a worldwide division of labour about

\footnotetext{
${ }^{9}$ On the "resource curse" see amongst others F. van der Ploeg and S. Poelhekke, "Natural Resources: Curse or Blessing?" Journal of Economic Literature 49, no. 2 (2011): 366-420; R.M. Auty, Resource Abundance and Economic Development (Oxford: Oxford University Press, 2001).

${ }^{10}$ On extractivism see Eduardo Gudynas, "Transitions to Post-Extractivism: Directions, Options, Areas of Action," in Beyond Development, ed. Miriam Lang and Dunia Mokrani (Amsterdam: Transnational Institute, 2013), 165-88. On neoextractivism, see Hans-Jürgen Burchandt and Kristina Dietz, "(Neo-) Extractivism - A New Challenge for Development Theory from Latin America,” Third World Quarterly 35, no. 3 (2014): 468-86. Extractivism has been extended beyond mineral extraction to include agriculture and forestry. On post-extractivism and counternarratives, see J. Martinez-Alier, et al., "Between Activism and Science: Grassroots Concepts for Sustainability Coined by Environmental Justice Organizations," Journal of Political Ecology 21 (2014): 19-60.

${ }^{11}$ Mattias Borg Rasmussen and Christian Lund, "Reconfiguring Frontier Spaces: The Territorialization of Resource Control," World Development 101 (2018): 388-99; Nancy Lee Peluso and Christian Lund, "New Frontiers of Land Control: Introduction," Journal of Peasant Studies 38, no. 4 (2011): 667-81.

${ }^{12}$ Alain Bihr, Le premier âge du capitalisme (1415-1763): Vol. 1. (L'expansion européenne Lausanne: Page deux, 2006). There are also those who disagree, seeing capitalism's history instead as either much longer (for example, Larry Neal and Jeffrey Williamson, The Cambridge History of Capitalism. 2 vols (Cambridge: Cambridge University Press, 2014), or as emerging in a very particular locale in Europe and becoming global only in the nineteeth century, most prominently Robert Brenner.

${ }^{13}$ Terence Hopkins and Immanuel Wallerstein, "Commodity Chains in the World Economy Prior to 1800," Review 10, no. 1 (1986): 157-70. See also Gary Gereffi and Miguel Korzeniewicz, eds. Commodity Chains and Global Capitalism (ABC-Clio, 1994); William G. Clarence-Smith and Steven Topik, eds. The Global Coffee Economy in Africa, Asia and Latin America: 15001989 (Cambridge: Cambridge University Press, 2003); Jennifer Bair, "Editors Introduction: The Political Economy of Commodity Chains," Journal of World-Systems Research 20, no. 1 (2014): 1-10 and see further this special issue.
} 
600 years ago, a system that typically connected rural commodity-producing regions in the periphery with processing industries and consumers, typically in cities located in what they called the 'core.' These production processes, they argued, were 'cross-cutting political jurisdictions,' expanding over time, and subject to structural transformations. ${ }^{14}$ Because the commodity chain concept sees commodities as 'containers of hidden social relations', it concentrates on people working on commodity frontiers, the places where they work, the conditions they work under and the social relations governing their work and production. ${ }^{15}$

Feminist scholars working in this tradition, importantly, have expanded the scope of the commodity chain to include the unwaged household work that produces labourers and the 'free gifts of nature' that contribute to the making of commodities and commodity frontiers. ${ }^{16}$ They have endeavoured, as Wilma Dunaway put it, to make visible those 'transfers of value that are embodied in commodities but do not show up in prices'. ${ }^{17}$

In recent years, global historians have picked up on some of these ideas. Studies on the history of particular commodities, for example, have persuasively illustrated the deep links between agriculture and industry, the countryside and the city and the household and production. These studies have revealed how the global emerged from local configurations and have shown the essential role played by the politics, ideas and collective actions of non-elite actors such as rural cultivators, especially in the Global South, in shaping commodity frontiers, and thus the political economy of global capitalism. ${ }^{18}$ Similarly, many scholars have been sensitive to the ecological dimension of economic and technological divergence between 'core' and 'periphery'. Environmental historian and historical geographer Jason W. Moore, for example, has argued that since for most of human history technological advances were slow and piecemeal, the global economy derived much of its growth from an unstinting expansion of vast frontiers of labour, food, energy and raw materials. ${ }^{19}$ Sidney Mintz made the point abundantly clear in his Sweetness and Power, observing how slave labour produced cheap sugar for the emerging British industrial proletariat. Slave-based sugar and cotton supplied calories and clothing that industrialising Britain could never have procured from its own soil. In the words of historian Kenneth Pomeranz, these processes provided Britain with ecological relief..$^{20}$

It is at this point that Jason W. Moore's argument that global capitalism is organized through frontiers becomes especially relevant. For him, these frontiers have expanded from one place to the next, transforming socioecological relations as they go, producing more and more goods and services that circulate through an expanding series of exchanges. Valued by a growing number of scholars from different disciplines as a problem-oriented transdisciplinary approach to historical processes, Moore's commodity frontier concept invites a radical rethinking of the commodity

\footnotetext{
${ }^{14}$ Hopkins and Wallerstein, "Commodity Chains," 158.

${ }^{15}$ Jane Collins, "A Feminist Approach to Overcoming the Closed Boxes of the Commodity Chain," in Gendered Commodity Chains: Seeing Women's Work and Households in Global Production, ed. Wilma A. Dunaway (Stanford: Stanford University Press, 2014), 27; Jane Collins, Threads: Gender, Labor, and Power in the Global Apparel Industry (Chicago: University of Chicago Press, 2003).

${ }^{16}$ Nancy Fraser, "Behind Marx’s Hidden Abode," New Left Review 86 (March/April 2014).

${ }^{17}$ Wilma A. Dunaway, "Women's Labor and Nature: The $21^{\text {st }}$ Century World-System from a Radical Ecofeminist Perspective," in Emerging Issues in the 21 ${ }^{\text {st }}$ Century World-System, ed. Wilma Dunaway (Praeger Press, 2003), 189. Joan Smith and Immanuel Wallerstein eds. Creating and Transforming Households. The Constraints of the World-Economy (Cambridge: Cambridge University Press, 1992).

${ }^{18}$ Sven Beckert, Empire of Cotton: A Global History (New York: Alfred A. Kopf, 2014); Ulbe Bosma, The Making of a Periphery: How Island Southeast Asia Became a Mass Exporter of Labor (New York: Columbia University Press, 2019).

${ }^{19}$ Jason W. Moore, Capitalism in the Web of Life: Ecology and the Accumulation of Capital (London: Verso, 2015); Alf Hornborg, J.R. McNeill, and Joan Martinez-Alier, Rethinking Environmental History. World-System History and Global Environmental Change (Lanham: Altamira Press, 2007).

${ }^{20}$ Sidney W. Mintz, Sweetness and Power: The Place of Sugar in Modern History (New York: Viking, 1985); Kenneth Pomeranz, The Great Divergence. China, Europe and the Making of the Modern World Economy (Princeton and Oxford: Princeton University Press, 2000), 274-8.
} 
chain approach from which it emerged. Commodity chain analysis starts from what its advocates have called 'the core' and works downstream towards peripheral locations of subaltern production, crop cultivation, mineral extraction and so on. The commodity frontier approach, in contrast, begins with the countryside - a significant departure. It moves analytically from chains of (labour) relations to frontiers of spatial expansion that include not only labour, but the incorporation and extraction of non-human nature.

Yet capitalism never changed solely by expanding in space and scale. It also experienced fundamental shifts in character, including in the dominant patterns of commodity frontier expansion. Analysing and understanding how these patterns varied across time and place, how and why such variations were institutionalized and how and why key dynamics changed requires a reflection on the periodization of capitalism. An influential approach here is that of Harriet Friedmann and Philip McMichael's work on successive food regimes. Concerned with 'the role of agriculture in the development of the capitalist world economy, and in the trajectory of the state system', their food regime concept has been debated, critiqued and carried further in the past 30 years. ${ }^{21}$ Recently, Friedmann has amended a rather rigid structural conceptualization of food regimes by bringing agency and social movements more centrally into the frame. For her, a regime is constituted by a 'relatively stable set of relationships' with 'unstable periods in between shaped by political contests over a new way forward'. ${ }^{22}$ Meanwhile, McMichael specified that the food regime is foremost an analytical device and historical method to pose specific questions about the structuring processes of the global political economy, and/or global food relations, at any particular moment. ${ }^{23}$ Food regimes as a concept have thus developed into a device for periodization and a proposal for a comparative historical method that links broad political-economic change to local agency and contestation.

\section{Commodity regimes}

All the approaches outlined above illuminate important aspects of the expansion of commodity frontiers during the past six centuries. Yet, each is limited in its own way. Much of the writing on the history of capitalism produced during the past 150 years privileges a perspective from the city, from industry and from labour outside the household; not surprisingly, considering that most of these authors were men who resided in cities located in industrializing countries. Yet, the vast majority of humanity has lived and worked, until very recently, in rural and domestic places, and it was in these places that many of the revolutions of capitalism have taken place. And while commodity histories and commodity chain analysis have persuasively shown the deep links between agriculture and industry and the countryside and the city, their focus on single commodities has limited their ability to capture the expansion of commodity frontiers across several centuries and around the world as a whole. Global historians have captured some of these general processes, but their all-too-frequent privileging of top-down perspectives and elite actors has led them to ignore how the global, including global commodity frontiers, has emerged from local configurations of social space and social power. Scholars who focus squarely on commodity frontiers have often concentrated on single factors to illuminate their dynamics, insisting, for example, on master explanations like the 'spatial fix' (Harvey and Moore) or the 'technical fix' (neoclassical

\footnotetext{
${ }^{21}$ Philip McMichael, "Global Development and the Corporate Food Regime," in New Directions in the Sociology of Global Development, ed. Frederick H. Buttel, and Philip D. McMichael (Bingley: Emerald Group Publishing Limited, 2005), 272; Harriet Friedmann and Philip McMichael, "Agriculture and the State System: The Rise and Fall of National Agricultures, 1870 to the Present," Sociologia Ruralis, 29, no. 2 (1989): 93-117; Philip McMichael, "Commentary: Food regime for thought," Journal of Peasant Studies, 43, no. 3 (2016): 648-70.

${ }^{22}$ Harriet Friedmann, "From Colonialism to Green Capitalism: Social Movements and the Emergence of Food Regimes," in New Directions in the Sociology of Global Development, ed. Frederick H. Buttel and Philip D. McMichael (Bingley: Emerald Group Publishing Limited, 2005), 227-64, and here 228.

${ }^{23}$ Philip McMichael, “A Food Regime Genealogy,” Journal of Peasant Studies 36, no. 1 (2009): 148.
} 
economists) and failing to historicize particular responses to particular moments of commodity frontier expansion. ${ }^{24}$ Last but not least, many discussions of contemporary commodity frontier dynamics (i.e. land grabbing, flex crops, extractivism) fall into the trap of emphasizing the newness of developments that go back many centuries and can only be understood via a historical perspective.

What we need, instead, is to analyse commodity frontiers through a historical approach that (1) keeps multiple frontiers in the view over a very long time period, (2) focuses on a variety of actors, including capitalists, rural cultivators (peasants and slaves, men and women, indigenous people and state bureaucrats), (3) takes both a global and a local view to scrutinize frictions, contestations and counter movements from the household to the international arena and (4) asks how commodity frontiers have transformed in fundamental ways over the past 600 years, producing new kinds of dynamics, encountering particular resistances and constructing new fixes.

The concept of commodity regimes allows us to identify moments in the history of commodity frontiers in which particular sets of labour relations and property rights, patterns of land ownership, forms of the insertion of capital, state policies and technologies come to define a given historical period. It is a meta-historical device that allows us to capture the ways in which different societal domains on commodity frontiers (ecological, technological, social and political) are organized and relate to one another; it allows us to periodize and subdivide as needed, while still understanding the unity of the diverse.

Over time, we see that commodity frontiers exhibited regular, albeit shifting, combinations of labour systems, property regimes, technologies and state interventions. Any systematic analysis of the long history of these frontiers needs to begin by acknowledging this diversity. But we also need to acknowledge certain patterns. Properly analysed, these patterns help us understand the changing character of commodity frontiers as a constituent in the historical development of capitalism.

We can distinguish, roughly speaking, four distinct commodity regimes during the past centuries of capitalism's history, with the transitions from one to the next propelled by key transformations such as the abolition of slavery, the Industrial Revolution, the emergence of powerful state bureaucracies both in the industrializing countries of the North Atlantic and the colonial peripheries, and over the course of the twentieth century, the massive concentration of corporate enterprises.

The first such regime, which lasted from the 1450s through the 1850s, can be termed an early capitalist commodity regime. It was characterized by direct and violent dispossession of people from land and nature and by unfree labour systems that included chattel slavery, peonage and indentured contract labour. ${ }^{25}$ Its forceful expansion was sanctioned by states, but its principal expansionary driver was merchant capital. The sugar commodity frontier is exemplary for this particular regime. Sugar production principally expanded because ever more land was violently taken out from underneath its native inhabitants, ever more workers were enslaved, and ever more capital moved from Europe into distant locations. Merchant capitalists and planters exerted a decisive influence on this commodity frontier, often ruling faraway places and organizing the day-to-day domination of labour. By the end of this period, maroonage and rebellion emerged as central social contestations, while technological advances propelled new and deeper forms of exploitation of both labour and nature.

\footnotetext{
${ }^{24}$ The idea that there are additional fixes besides the well-known spatial fix has been expressed by Beverly Silver in her book Forces of Labor: Worker's Movements and Globalization Since 1870. (Cambridge: Cambridge University Press, 2003), 76. She mentions among others the technological/organizational fix. See also Giovanni Arrighi, "Spatial and Other "Fixes" of Historical Capitalism," [https://irows.ucr.edu/conferences/globgis/papers/Arrighi.htm], 2003 and Marcel van der Linden, Workers of the World: Essays Toward a Global Labor History (Leiden: Brill, 2008).

${ }^{25}$ An extensive investigation of these changing labour relations is conducted by the Global Collaboratory on the History of Labour Relations, based at the International Institute of Social History in Amsterdam: https://collab.iisg.nl/web/ labourrelations. See also Karin Hofmeester and Marcel Van der Linden eds. Handbook Global History of Work (Berlin, etc.: De Gruyter, 2018).
} 
The second regime, from the 1850s to the 1970s, can be described as andustrial commodity regime. It was characterized by the massively expanding use of fossil energy, soaring industrial and state demand for commodities and the rise of multinational capital, global bulk commodity markets and new transport and communication technologies. These factors reinforced infrastructural capabilities ranging from the telegraph to railroads, shaping the conditions under which commodity frontiers expanded, including the contractual mobilization of land and labour.

While the forms this transformation took were complex and varied across time and space, four central features can be distinguished: the conversion of a system of customary land rights into legally defined titles to land ownership; the transformation of the concept of property from ambiguously defined areas to concretely defined, possibly enclosed, physical spaces; the rationalization of the use of such demarcated landed property as a form of capital and the increased privatization of the earth's surface through dispossession and displacement of peasants and indigenous populations. Sharecropping, tenant farming, indentured servitude and wage labour increasingly replaced non-economic labour coercion such as enslavement. Massive colonial projects fuelled the commodification of land, while land grabs abolished communal peasants' rights and developmental projects or state-sponsored collectivization schemes led to further expropriation and displacement. Agricultural science, in turn, brought productivity leaps, eventually leading to the Green Revolution of the 1960s. Like the previous commodity regime, the industrial commodity regime was always contested, with labour activism and anti-colonial movements joining older forms of resistance.

The industrial commodity regime had enormous staying power and was propelled to new heights by the rapid economic expansion in the three decades after the Second World War. However, by the 1970s, it started to unravel and be replaced by a new corporate commodity regime. Slow economic growth hit numerous commodity-producing countries particularly hard, reducing their governments' abilities to mitigate market volatility and forcing them to accept structural adjustment programmes. This reinforced the changing role of the state vis-à-vis transnational corporations and financial institutions, as well as new global political divisions amongst and between North and South, simultaneously reproducing and remapping imperial, colonial and Cold War political geographies. The concentration of power in the hands of a few producers took a quantum leap as commodity trade and financial institutions became tightly connected from the 1980s on. Capitalist agriculture created new commodified inputs (seeds, fertilizers, pesticides, etc.) and legal protections for corporate ownership, resulting in further power concentrations at commodity frontiers. A massive contraction of land rights accelerated the growth of a rural proletariat on a world scale, and resistance movements acquired a transnational character. ${ }^{26}$

Cracks in the corporate commodity regime became visible with the Great Recession and the world food crisis in 2008, spurring a fourth - still tentative - contemporary commodity regime. In this emerging regime, key elements of the previous regimes are reintegrated and intensified. For instance, firms already entrenched at the top of commodity markets and financial actors looking for new investment opportunities have come to own or finance increasing amounts of land around the world, largely through dispossession, often with the assistance of state power, best expressed in the newly fashionable public-private partnerships (PPPs). Green capitalism, built on the cooptation of sustainability discourse, continues to create new products and frontiers for accumulation, amongst them organic foods, biofuels and the optimistically named clean coal. ${ }^{27}$ Rising authoritarianism around the world is pressuring people and environments on commodity

\footnotetext{
${ }^{26}$ See Joe Bandy and Jackie Smith, eds. Coalitions Across Borders: Transnational Protest and the Neoliberal Order (Lanham Md.: Rowman \& Littlefield, 2005); Saturnino M. Borras Jr., Marc Edelman, and Cristóbal Kay, Transnational Agrarian Movements Confronting Globalization (New York: Wiley-Blackwell, 2008).

${ }^{27}$ See Scott Prudham, "Pimping Climate Change: Richard Branson, Global Warming, and the Performance of Green Capitalism," Environment and Planning A 41 (2009): 1594-613; Victor Wallis "Beyond 'Green Capitalism'," Monthly Review 61, no. 9 (2010): 32-48; Friedmann, "From Colonialism to Green Capitalism".
} 
frontiers in South America, the USA, South East Asia and elsewhere. At the same time, new dynamics are coming into view in this post-2008 era that Klaus Schwab, Executive Chair of the World Economic Forum, has called the 'fourth industrial revolution' ${ }^{28}$ Companies (often with state assistance) are expanding into radically new production and information technologies, including new automated (robot) labour in manufacturing, households and agriculture. Relatedly, new digital infrastructures that extract data and mediate between different groups have become increasingly important for commodity frontiers. Examples of what Nick Srnicek calls platform capitalism include agricultural implements manufacturer John Deere's data collection systems that record farmers' activities and commodify the data and mobile phone-based money transfer and (micro)financing services such as Vodafone's M-Pesa that operate in East Africa and elsewhere, and China's new 'Study the Great Nation' social platform that collects user data for surveillance and advertising. ${ }^{29}$ As this regime is still unfolding, questions about which processes and relations will be most important, which will spur or encounter the most resistance, and what forms that resistance will take remain.

These four regimes have engendered widely divergent forms of expansion and exploitation, showing capitalism to be highly adaptive and flexible. And like capitalism more broadly, each regime contains profound tensions, generating fierce contestation. Approaching the history of capitalism through commodity regimes speaks against a teleological or linear interpretation of the relationship between capitalism and the countryside, as Figure 1 clearly shows, and aids us in uncovering capitalism's shifting historical and spatial logic. Figure 1 is our effort to describe in a tentative way and at the most general level how we propose to investigate frontier expansion as a series of cumulative frictions and fixes.

\section{Commodity regimes and their frictions}

The expansion of commodity frontiers was not a smooth unfolding of one universal logic or of unstinting human progress, but a series of regimes that transformed themselves in quite fundamental ways at certain moments. These transformations occurred because each regime ran into frictions that eventually made the further expansion of commodity frontiers impossible without fundamental changes. Preliminary investigations suggest that these regimes succeed each other at an accelerating pace, going from 400 years for the first regime to 30 years for the third. Market convergence and the increased momentum of technological change as well as growing resistance might account for fundamental frictions occurring more frequently. But these are assumptions that we want to test. In doing so, our point of departure is that commodity regimes encounter frictions along three central axes: (1) ecological frictions, (2) competition for land and labour (3) and social resistance, including counternarratives that contest the existing commodity regime.

To begin with, ecological frictions have imposed an important set of limitations on commodity frontier expansion. In the early phases of capitalism, ecological frictions such as declining soil fertility forced the production of agricultural commodities or minerals to move into new areas. Later, crippling diseases that swept through populations of uniformly bred crops and livestock instigated the quest for disease-resistant plant varieties, broad-spectrum pesticides and fungicides, more powerful vaccines and tightly controlled production systems with labour-disciplining biosecurity measures. Ecological damage caused by commodity agriculture or extraction rendered many frontiers unproductive or uninhabitable, often causing the end of the production of this particular commodity at this location. Deserted mining regions around the globe, the problem of severe water shortages and salinization surrounding the irrigated cotton fields in Central Asia, the wheat frontier in the USA and its degeneration into the infamous Dust Bowl in the 1930s are all examples of collapsed commodity frontier zones caused by ecological frictions.

\footnotetext{
${ }^{28}$ https://www.weforum.org/about/the-fourth-industrial-revolution-by-klaus-schwab.

${ }^{29}$ Nick Srnicek, Platform Capitalism (Cambridge, UK; Malden, MA: Policy, 2016).
} 


\begin{tabular}{|l|l|}
\hline Commodity Regimes and Frictions & Fixes* \\
\hline $\begin{array}{l}\text { 1450s-1850s: Early Capitalist Commodity Regime } \\
\text { Frictions: Spatial expansion of commodity } \\
\text { production: land dispossession, soil exhaustion, } \\
\text { deforestation, unfree labor. Slave rebellions. }\end{array}$ \\
\hline $\begin{array}{l}\text { 1850s-1970s: Industrial Commodity Regime } \\
\text { Frictions: Staggering growth and expansion of global } \\
\text { bulk commodity production /consumption/trade (and } \\
\text { impacts, as above). Anti-slavery sensibilities and need } \\
\text { for cheap labour. Population growth. Expansion of } \\
\text { state capacity. Intensification of technology. }\end{array}$ \\
\hline $\begin{array}{l}\text { 1970s-2008: Corporate Commodity Regime } \\
\text { Frictions: Expansion and overproduction of } \\
\text { commodities (and impacts). Growing power of } \\
\text { transnational corporations, with weakened state } \\
\text { regulations. Vertical integration and privatization. } \\
\text { Structural adjustment. Casualization of labour. }\end{array}$ \\
\hline $\begin{array}{l}\text { 2010s-present: Contemporary Commodity } \\
\text { Regime }\end{array}$ \\
Frictions: Financial, food, energy, climate and \\
environmental crises. Commodity expansion (and \\
impacts). Rise of China and BRICS. Financialization \\
and debt. Mounting authoritarianism. Transnational \\
rural resistance. Green capitalism or 'sustainability \\
fix.'
\end{tabular}

Figure 1. Commodity regimes, frictions and fixes.

Likewise, frictions arising from competition for land and labour have destabilized many commodity frontier zones. Rebellions of enslaved and servile women and men were a permanent feature of the frontier zones during the early capitalist commodity regime. Slavery became increasingly untenable due to resistance by enslaved people such as the revolution in SaintDomingue in 1791 and the large-scale uprising in Jamaica in 1832, as well as the emergence of an abolitionist movement. Labour shortages were a perennial problem for commodity frontiers; in fact, during the many centuries in which mechanization proceeded slowly, labour supplies were the main limiting factor for commodity production. Once slavery was abolished and tropical commodity agriculture left its plantation enclaves, it increasingly inserted itself into existing rural societies, where it had to compete for land and labour. Thus the expansion of global capitalism increasingly encroached upon existing land rights, often using large-scale destruction of communal land ownership and outright dispossession and displacement of peasants and indigenous populations. This massive accumulation through dispossession has been a source of permanent, often violent, conflict.

Across the four regimes, commodity regime expansion produced other social frictions as well. As merchants, chartered companies, colonial officials, mining capitalists and frontier planters, amongst others, expanded into new territories and new productive activities, appropriated new land, extracted new materials and incorporated new labour, their ongoing attempts to externalize the social and environmental costs of production and reproduction were met with resistance. Coupled with ecological limits, such resistances can prefigure and compel regime change, pushing capital to seek new frontiers. During the early capitalist regime, for instance, revolt and desertion (maroonage) were responses to enslavement and servitude and helped propel the shift to sharecropping and wage labour. During the industrial regime, strikes, working-class political 
mobilizations and unionization, together with anti-colonial movements, joined rebellion and escape as forms of insurgency. Later, as corporate-headed transnational commodity chains integrated global production in the corporate regime, resistance has also become transnational. Workers struggled against capital's 'race to the bottom', indigenous communities against the polluting and degrading activities of transnational corporations that often operate with near impunity, peasants against the incursions of transnational capital into agrarian spaces. In some cases, resistance also provided counternarratives and counterproposals for different ways of organizing political, economic, social and ecological life - in recent years, for example, by seeking collaborative, locally embedded, equitable or non-growth-based forms of production. Because counter movements suggest some of the key themes around which people are exploited or oppressed, studying resistance within regimes is a crucial part of defining and analysing the regimes themselves - and helping to explain how over time they changed fundamentally.

\section{Commodity regimes and their fixes}

Frictions and resistances were part of each commodity regime over the centuries, usually culminating in systemic crises. In response, new commodity regimes emerged, characterized by particular fixes or combinations of fixes. Each ensemble was particular to particular moments in the history of global capitalism. The fixes, as described in Figure 1, were (A) the spatial fix, (B) the technological fix, (C) the state-led fix and (D) the corporate fix. Although each new fix was hailed as the master key to resolving the then-current limits to commodity frontier expansion, they were usually not entirely new. Moreover, older fixes did not disappear. Spatial fixes, for example, remain powerful today, usually at the expense of tropical rain forests, grasslands, indigenous communities and biodiversity.

Nonetheless, the spatial fix was most pronounced during the early capitalist commodity frontier regime, when the state was distant and quite weak and most increases in output came from additional inputs of land and labour. Until the late eighteenth century, the consequences of soil exhaustion caused by sugar, tobacco or coffee plantations, for example, were almost always overcome either by using additional labour to perform manuring or by adding more land for crop rotation. Labour shortages were addressed by immigration of either free or enslaved workers, as happened in most of the plantations of the New World. From the late eighteenth and particularly the early nineteenth century onward, a new set of fixes emerged to join the continuing spatial expansion. In the early stages of capitalism, technology had only a limited impact on productivity. The Industrial Revolution changed this, as it resulted in massive mechanization of both agriculture and mining and immense improvements in transportation, although these innovations entered the commodity frontiers unevenly and increased rural inequalities through class differentiation and lay the ground for future ecological distribution conflicts.

Increasingly, the state came to play a more prominent role in commodity frontier expansion. Where the expansion of commodity frontiers had previously been driven by a particularly violent type of capitalism exerted by merchant capital and sanctioned by the state, in the nineteenth and twentieth centuries states attained the infrastructural capability needed to shape the conditions under which frontiers operated. Infrastructure construction, financial legislation, sponsored migration of contract labour and legislation and implementation of new property rights regimes all featured as prominent new forms of state interventions. While technology-enabled global commodity production to soar after the systemic crisis that attended the abolition of the slave trade and slavery itself, these technological innovations would not have materialized without the new role played by the state.

Science, moreover, produced leaps in agricultural productivity, including the Green Revolution at the end of the industrial commodity regime. Differential access to technology and the ways 
that capitalist agriculture created new commodified inputs (seeds, fertilizers, pesticides, etc.) engendered new dependencies for farmers, ${ }^{30}$ thus leading to further concentrations of power at the commodity frontier. The current stage of biotechnology enables the integration of the food and energy sectors and a profound appropriation of life through seed patents and intellectual property protections, leading to further large-scale dispossessions. In fact, over time, the stateled fix has paved the way for a transnational corporate enterprise to become the dominant force on commodity frontiers, which continues - not without contestation - in the contemporary regime.

Capitalism has been driving the creation of increasingly integrated and complex commodity chains, massively changing the relationship between commodity frontiers and processing industries. Significant convergence of commodity prices appeared by the late eighteenth century; information systems connected the global countryside with industrial centres by the mid-nineteenth century; the concentration of power in the hands of a few end producers intensified during the twentieth century, especially in the 1980s when commodity trade and financial institutions became tightly connected. Currently, a narrow range of mostly transnational corporations controls much of the expansion of commodity frontiers through direct ownership of land and means of production and contracting, subcontracting, digital data collection and general control of commodity circulation. ${ }^{31}$ Much of the economic risks and the environmental and social costs of corporate-led production are dumped on marginalized people and places, while new calls for sustainability are co-opted into opportunities to deepen Green Capitalism in the new commodity regime.

The framework of commodity regimes takes commodity frontiers as an analytical point of departure, sensitizing us to geopolitical shifts, the role of the state, technology, ecology, and last but not least, local agency. This is to say that capitalism develops not only through incorporation and commodification, but also through what resists it. Non-human nature is not flat, constant or given: soils give out, water becomes scarce or toxic, wells run dry, 'weeds' and microorganisms develop resistance to agrochemicals and antibiotics. At the same time, social movements and civil society initiatives compel capital to adjust to the demands of organized groups of people, sometimes creating new avenues and segmented markets for capital such as fair trade and organic labelling in food, and sometimes creating a barrier for capital to overcome, such as wage labour.

\section{A research strategy}

It is challenging to translate the framework of commodity regimes into a workable research strategy; this challenge, of course, also pertains to global history's project of making wide-ranging comparisons across large time spans and geographic regions. ${ }^{32} \mathrm{~A}$ commodity frontiers research project

\footnotetext{
${ }^{30}$ See David Goodman, Bernardo Sorj, and John Wilkinson, From Farming to Biotechnology: A Theory of Agro-Industrial Development (Oxford: Basil Blackwell, 1987). The authors describe this process as appropriationism, whereby 'elements once integral to the agricultural production process are extracted and transformed into industrial activities and then reincorporated into agriculture as inputs' (p. 2). Through state policies and agribusiness-led markets, farmers adopt these technologies, entering into production treadmills that create dependencies, competitive imperatives in price-governed markets, and systemic ecological degradation. See also Philip Howard, "Visualizing Consolidation in the Global Seed Industry: 1996-2008," Sustainability 1, no. 4 (2009): 1266-87.

${ }^{31}$ See McMichael, “A Food Regime Genealogy”; Jennifer Clapp and Doris Fuchs, eds. Corporate Power in Global Agrifood Governance (Cambridge Mass.: MIT Press, 2009).

${ }^{32} \mathrm{We}$ refer to some useful reflections: Philip McMichael, "Incorporating Comparison within a World-Historical Perspective: An Alternative Comparative Method," American Sociological Review, 55, no. 3 (1990): 385-97; Gareth Austin, "Reciprocal Comparison and African History: Tackling Conceptual Eurocentrism in the Study of Africa's Economic Past," African Studies Review 50, no. 3 (2007): 1-28; P. Parthasarathi, "Comparison in Global History," in Writing the History of the Global. Challenges for the 21st Century, ed. M. Berg (Oxford, Oxford University Press, 2013), 69-82.
} 
directly engages with ongoing debates about the ambitions, promises and limits of global and world history. It requires building collaborative and discipline-crossing research networks. It offers methods and sources for a history that aims to surpass or delegitimize the old Eurocentric stories of the rise of a unified world. ${ }^{33}$

We aim for an inductive approach that studies localized experiences and global systemic movements and past experiences and contemporary problems within a single analytical framework. This requires that we overcome the fragmented and individualized character of archival research and fieldwork, which, because they are so labour intensive, usually produce geographically and temporally limited work. The immense library of existing case studies does not add up to a systematized body of knowledge. Another challenge - one that again pertains to global history more broadly - is to move beyond privileging the national level as a unit of analysis. Many historical indicators of development - per capita income, demography, migration, balance of trade, etc. - are only available at the national level, but commodity frontier zones are usually subnational units, and sometimes cross national borders. ${ }^{34}$ National data collections remain indispensable, but data collection at the subnational and transregional level is equally important.

While still difficult, an inductive and multi-scalar approach is increasingly feasible thanks to innovative technologies of data gathering, analysis and visualization. Digital humanities techniques let us look at a myriad of sources to illuminate the workings of commodity frontiers at the local level and may release us from over-relying on data aggregated at the national level. Publications on particular commodity frontier zones that span decades and perspectives are already available in digital format, and we can draw on their research findings. Moreover, since frontier zones are marked by the commodification of land and labour, they have been relatively well documented by colonial administrations, revenue records and so on. In recent years archives have been digitizing their holdings of documents, historical artefacts and newspapers. Archaeologists working on the Baltics, Southern Spain and the Eastern Mediterranean, for example, have employed excavations, paleoenvironmental sources and laser techniques that would help us reconstruct even the oldest commodity frontiers. ${ }^{35}$

If these sources can be digitally connected and automated data-mining processes applied to them, it becomes feasible to extract a wide range of data from very disparate sources in different languages. What is more, semantic technology can help us create structured data sets from immense collections of fuzzy data. Analysis of these sources within a global comparative context, enhanced by visual representations such as maps and graphs, can provide clues for new hypotheses to be tested against the assembled corpus of data or even Linked Open Data. These technologies facilitate the integration of geographic knowledge from diverse data sources, and they have

\footnotetext{
${ }^{33}$ Richard Drayton and David Motadel, "Discussion: The futures of global history," Journal of Global History, 13, no. 1 (2018): 1-21; Eric Vanhaute, "Who Is Afraid of Global History? Ambitions, Pitfalls and Limits of Learning Global History," Osterreichische Zeitschrift Fur Geschichtswissenschaften 20, no. 2 (2009): 22-39; Patrick O’Brien, "Historiographical Traditions and Modern Imperatives for the Restoration of Global History," Journal of Global History, 1, no. 1 (2006): 3-39, 38; Dominic Sachsenmaier, "World History as Ecumenical History," Journal of World History, 18, no. 4 (2007): 465-89; Barbara Weinstein, "History Without a Cause? Grand Narratives, World History, and The Postcolonial Dilemma," International Review of Social History, 50, no. 1 (2005): 71-93, 80; Kenneth Pomeranz, "Writing About Divergences in Global History. Some Implications for Scale, Methods, Aims, and Categories," Writing the History of the Global. Challenges for the 21st Century, ed. M. Berg (Oxford: Oxford University Press 2013), 117-28.

${ }^{34}$ See, for example, the Maddison Conference Board: https://www.conference-board.org/data/economydatabase/index.cfm? id $=27722$ and https://www.clio-infra.eu/.

${ }^{35}$ Aleksander Pluskowski, Adrian J. Boas, and Christopher Gerrard, "The Ecology of Crusading: Investigating the Environmental Impact of Holy War and Colonisation at the Frontiers of medieval Europe," Medieval Archaeology 55 (2011): 192-225. See also the Medin project (Mediterranean Insularities: Space, Landscape and Agriculture in Early Modern Cyprus and Crete. https://medins.ims.forth.gr/,
} 
been developing rapidly, offering the promise that they will soon become more customerfriendly. ${ }^{36}$

To deliver on the promises of a commodity frontiers centred analysis of global capitalism we need to draw on approaches and disciplines that often stay aloof from one another. ${ }^{37}$ Combining data gathering and analysis techniques with fieldwork will bridge the divide between disciplines that study the past and those that study the present. Global historians need to draw on the methods of ecological economists and other social scientists - on the Environmental Justice Atlas https://ejatlas.org/, for example - to map today's ecological inequalities. Combining archival research, fieldwork and digital techniques and deploying an inductive methodology at different spatial and time scales will enable us to understand the shifts of key commodity frontiers and the emergence of particular commodity regimes, and thus to redraw our understanding of global capitalism.

Studying the global history of commodity frontiers is crucial to coming to terms with important aspects of world history over the past six centuries. But this project is just as important when it comes to understanding our contemporary dilemmas. Two recent reports commissioned by the European Union recommend that the EU considers its giant global ecological footprint. ${ }^{38}$ These reports - along with international reporting more generally - suggest that we have arrived at a new state of unsustainability. But as alarming as this is, when we look at commodity frontiers over the very long term, we immediately see that our contemporary dilemmas are not new. The consumption of massive amounts of extra-European resources is an old story that goes back at least 600 years and has played a major role in Europe's economic ascendancy. There is a similar, though shorter story for the USA and other emerging powers that arrange their economies through a mix of domestic production and global trade in commodities that usually originate in the countryside.

To disentangle the complexities that may derail today's attempts to frame a global agenda of sustainable growth, we have to understand in new historical depth the dynamics of appropriation of nature, enclosures of land, regimes of labour control and transfers of capital and knowledge and the concomitant elimination of ecological and social knowledge. At the same time, global history can deliver on some of its fundamental promises by looking systematically at global change over very long time periods while remaining attentive to history told from the bottom-up. A new global social history will allow us to analyse consecutive commodity regimes and understand the ways they have created unequal power relations and massive inequities that shape the present. Studying commodity frontiers can help us identify historical capitalism as a process rooted in a profound restructuring of rural societies and their relation to nature and lets us connect processes of extraction and exchange with degradation, adaptation and resistance in rural peripheries. When we look at the history of the sixteenth-century sugar frontier or the mid-twentieth-century soy frontier as moments in the unfolding of various commodity regimes over the past six centuries, we gain not just novel perspectives on the history of capitalism, but also on our contemporary dilemmas. Global historians can make a unique contribution to this conversation.

\footnotetext{
${ }^{36}$ See, for example, the work by Reinaldo Funes of Cuba's Fundación Nuñez Jimenez who has been leading the way in developing a historical GIS for Cuba, focused on mapping changing land use and ownership, the spread of the commodity-plantation economy and its environmental impact. http://www.fanj.org.

${ }^{37}$ For an extensive discussion of transdisciplinarity, see Eve Darian-Smith and Philip McCarty, "Beyond Interdisciplinarity. Developing a Global Transdisciplinary Framework," Transcience 2 (2016): 1-26, and Id., The Global Turn. Theories, Research Designs, and Methods for Global Studies (Berkeley: University of California Press, 2017).

${ }^{38}$ Feasibility study on options to step up EU action against deforestation (January 2018); Study on the environmental impact of palm oil consumption and on existing sustainability standards (February 2018).
} 
Sven Beckert is Laird Bell Professor of History at Harvard University, where he teaches the history of the USA and co-directs the Weatherhead Imitative on Global History. Beckert has been a fellow of the Guggenheim Foundation, the Alexander von Humboldt Foundation and the American Council of Learned Societies, amongst others. His latest book, Empire of Cotton: A Global History, won the Bancroft Award, the Alfred D. Chandler Jr. Award, the Taft Award, the Cundill Prize for Academic Excellence and was a finalist for the Pulitzer. The New York Times listed it as one of the ten best books published in the USA in 2015. Currently, Beckert is at work on Capitalism: A Global History, to be published by Penguin Press.

Ulbe Bosma is Senior Researcher at the International Institute of Social History and Professor of International Comparative History at the VU University in Amsterdam. His main fields of interest are plantation societies, commodity production and colonial migrations. Among his recent publications are The Sugar Plantation in India and Indonesia, Industrial Production 1770-2010 (Cambridge University Press, 2013) and The Making of a Periphery. How Island Southeast Asia Became a Mass Exporter of Labor (Columbia University Press, 2019). He is currently working on a global history of sugar.

Mindi Schneider is Assistant Professor in the Sociology of Development and Change at Wageningen University, the Netherlands. She is a development sociologist with specialization in agrarian political ecology, the political economy of development, and commodity studies. She has published extensively on the capitalist transformation of food and farming in China, including analyses of the metabolic rift, state-agribusiness power, the material-cultural politics of dispossession, rural-urban relations and contestations, and rural activism. She is senior editor of the open access journal, Commodity Frontiers.

Eric Vanhaute is Professor in Economic and Social History and World History at Ghent University, Belgium. He has published extensively about agrarian and rural history, the history of labor markets and social inequality, and world history. His latest book is Peasants in World History (Routledge, 2021).Together with Claudia Bernardi he is working on a book project Global History of the Living Planet. A Human Narrative.

Cite this article: Beckert S., Bosma U., Schneider M., and Vanhaute E. 2021. Commodity frontiers and the transformation of the global countryside: a research agenda. Journal of Global History 16: 435-450, doi:10.1017/S1740022820000455 